\title{
NASZ DRAMAT EROTYCZNY WITOLDA GOMBROWICZA — „EUROPEJSKOŚĆ” NA SPRZEDAŻ
}

\author{
Agnieszka CZYŻAK (Uniwersytet im. Adama Mickiewicza, Poznań) \\ ORCID: 0000-0001-8918-5264
}

Lektura tekstów pisarzy znanych, uznanych, powszechnie rozpoznawalnych obciążona jest bagażem wcześniejszych interpretacji, zwłaszcza wtedy, gdy istnieje podręcznikowa (szkolna) wykładnia ich dzieł. Nieuchronne poszukiwanie ,śladów autora” w każdym $\mathrm{z}$ jego utworów $\mathrm{z}$ reguły wyznaczane bywa przez wcześniej zadekretowane w gronie znawców aksjologiczne porządki. Michał Głowiński przekonywał w książce Gombrowicz i nadliteratura:

Tajemnica Gombrowicza polega na tym właśnie, że nawet z najtańszego, czasem jawnie tandetnego materiału, przeznaczonego, jakby się wydawać mogło, na konstrukcje, mające zaspokajać potrzeby tych, co ubodzy duchem, wznosi budowle najszlachetniejsze, mistrzowskie i wyrafinowane. Na tym zasadza się jedna z niezwykłości jego nadliteratury ${ }^{1}$.

W przypadku Witolda Gombrowicza jedną z ważniejszych dyrektyw lekturowych okazuje się poszukiwanie (i odrzucanie) mylnych tropów oraz odnajdywanie skrywanego pod subwersywnymi gestami przesłania. Jeśli natomiast mowa o niewielkim objętościowo zbiorze tekstów, wydawanych pod wspólnym tytułem Nasz dramat erotyczny, takim mylnym tropem jest sugerowane w tytule przyjęcie zbiorowej perspektywy oglądu zjawiska oraz pozorne obiektywizowanie wniosków dotyczących reguł wspólnotowego życia.

${ }^{1}$ M. Głowiński, Gombrowicz i nadliteratura, Kraków 2002, s. 9. Badacz uściślał: „tandeta budulca, niezależnie czy skojarzonego z tym, co genetycznie wielkie, czy też występującego w postaci mniej lub bardziej czystej, nie przesądza o marności końcowego wytworu. Przeciwnie, tworząc nadliteraturę, wielki pisarz jest kimś w rodzaju Midasa, który swym dotknięciem przemienia wszystko w złoto, czyli w arcydzieła" (tamże, s. 10). 
W Naszym dramacie erotycznym, powstałym w połowie lat 40. XX wieku, współczesny odbiorca Gombrowicza może na przykład z pewnym zaskoczeniem odkryć taką oto diagnozę:

Europejczyk będzie próbował zdobyć swoją wybrankę popisując się męską urodą, stanowczością, energią, siłą. Południowy Amerykanin będzie raczej starał się zaspokoić jej pragnienia, przypodobać się jej. Europejczyk nie będzie tak bardzo obawiał się utraty kobiety, bo nie cała poezja jego życia do niej się sprowadza; natomiast południowy Amerykanin tracąc swoją dziewczynę zostaje skazany na samotność i ma już tylko przed sobą perspektywę przesiadywania w kawiarni i wymieniania dowcipów z przyjaciółmi, którzy nie zawsze są przyjaciółmi prawdziwymi².

Zaskakująca jednoznaczność w ocenie skłonności przypisywanych mieszkańcom oddzielonych Oceanem Atlantyckim kontynentów oraz sugerowanie istnienia „kontynentalnej” tożsamości budzić dziś może jedynie sprzeciw. Podobnie rzecz się ma z pozornym (pozorowanym) podziwem dla jednych oraz pozbawionym realnych podstaw współczuciem wobec drugich.

Wątpliwości budzą także znajdujące się w poszczególnych rozdziałach oczywiste (a zatem i spodziewane) zastrzeżenia, osłabiające kategoryczność stawianych tez i rozsadzające schematyczność ujęcia prezentowanych zagadnień:

nie wolno zapominać ani na chwilę, że wszystko, co tu mówimy, jest z konieczności uproszczone, niesprawiedliwe i przesadzone [...] Europa często okazuje się tak bardzo nieokrzesana, płaska, sztuczna i odrażająca, że w istocie młoda i świeża Ameryka nie ma jej czego zazdrościć ${ }^{3}$.

Zastrzeżenia te jednak — przy bliższym oglądzie — służą przede wszystkim deprecjonowaniu „starej” Europy jako całości i sugerowaniu, że jedynie niektóre elementy jej tradycji mogą się okazać użyteczne, o ile zostaną przemyślnie wykorzystane w procesie „naprawiania” erotycznych relacji — w owym czasie jakoby bardziej dzielących, niż łączących mieszkańców Ameryki Południowej.

Dzisiejsza lektura Naszego dramatu erotycznego Witolda Gombrowicza nasuwa więcej wątpliwości niż prostych przyporządkowań. Pojawić się może nawet pytanie o sens tłumaczenia i wydawania współcześnie zbioru starych gazetowych artykułów pisarza, które równie dobrze mogłyby pozostać tzw. „nieznanym epizodem z życia twórcy". Odpowiedź na tego rodzaju wątpliwości ze strony przywiązanych do tradycji badawczych historyków literatury będzie oczywiście jednoznaczna — należy dążyć do poznania i zinterpretowania całości spuścizny, by móc tworzyć swego rodzaju „,pełne” obrazy pisarstwa niezaprzeczalnie wybitnego autora. Odpowiedź zwolenników adaptowania teorii Pierre'a Bourdieu do procesów zachodzących we współczesnych obiegach komunikacyjnych również będzie zrozumiała — poszukiwanie społecznych, ideologicznych i politycznych uwarunkowań nie tylko powstawania, ale i późniejszej recepcji tekstów kultury, pozwala śledzić przemiany zbiorowej świadomości ${ }^{4}$. Jednocześnie nazwisko Gombrowicza to marka, która się sprzedaje, zatem wydanie każdego tekstu jego autorstwa jest oczywiste, bowiem obliczone na spodziewany zysk ${ }^{5}$.

\footnotetext{
${ }^{2}$ W. Gombrowicz, Nasz dramat erotyczny, Kraków 2003, s. 60.

${ }^{3}$ Tamże, s. 61.

${ }^{4}$ Zob.: Literatura polska po 1989 roku w świetle teorii Pierre'a Bourdieu. Podręcznik, red. G. Jankowicz, P. Marecki, M. Sowiński, Kraków 2015.

${ }^{5}$ Zob. także: D. Antonik, Pisarz jako marka. Literatura w kulturze audiowizualnej społeczeństwa informacyjnego, Kraków 2014.
} 
Tymczasem zwykły czytelnik otrzymuje tekst sfalsyfikowany na tak wiele najrozmaitszych sposobów, że może nawet wątpić, czy jest to autentyczny fragment dzieła pisarza. Artykuły pisane pod pseudonimem Jorge Alejandro, choć zapowiadają „,obiektywny i naukowy" ogląd społecznych zjawisk, wydają się przede wszystkim, na pierwszy rzut oka, zbiorem dyletanckich dywagacji niezakotwiczonych nie tylko w żadnych badaniach, ale i przeciętnej wiedzy o prawidłowościach zbiorowego życia. Podmiot wypowiedzi sugeruje swą tożsamościową przynależność do „wspólnoty południowoamerykańskiej” - cokolwiek miałoby to wówczas znaczyć — oraz deklaruje znajomość „europejskich realiów” wynikającą jakoby z dłuższego pobytu na Starym Kontynencie. Powstające w latach 1944-1945 teksty całkowicie ignorują rzeczywistość historyczną — nie ma w nich sygnałów świadczących o znajomości ówczesnych wypadków dziejowych, a był to przecież czas, w którym Europa oraz fundamenty jej istnienia legły w gruzach. Dopiero bardziej uważna lektura pozwala dojść do wniosku, iż owe artykuły sprzed siedemdziesięciu lat pozostają mimo wszystko czymś więcej niż zgodnie z wstępną zapowiedzią Rity Gombrowicz — „dokument poświadczający wysiłki, aby jakoś przetrwać na argentyńskim wygnaniu".

Twórczość Gombrowicza zawsze funkcjonowała w centrum sporów o tzw. „literaturę narodową" i wspólnotowe dziedzictwo literackie oraz budziła emocje wywoływane pozaartystycznym aspektem jego dzieł. Skutkowało to między innymi naprzemiennym włączaniem i usuwaniem jego utworów z list lektur szkolnych. Być może żyjemy dziś w epoce - jak twierdzi prowokacyjnie Jerzy Franczak — gdy Gombrowicz:

wyskoczył na klasyka i bywa coraz częściej upupiany jako pisarz konserwatywny prowokujący ideowych lewicowców ziemianin, wróg egalitaryzmu i piewca przyrodzonej nierówności albo „wielki wychowawca Polaków”, którego dzieło kontynuował kardynał Wyszyński ${ }^{7}$

I rzeczywiście inkryminowani przez Franczaka postępowi „ideowi lewicowcy” znajdą w Naszym dramacie erotycznym wiele dowodów na poparcie swoich tez. Gombrowicz przekonywał na przykład, że wszystko, co w dziedzinie europejskiego ,erotycznego postępu” było „teoretyczne i wydumane (na przykład osławiony ruch kobiecy na rzecz absolutnego zrównania kobiet z mężczyznami) wnet popadło w zupełną śmieszność", by dodać uwagę pozornie aprobatywną, twierdząc, iż „,właśnie takie burze w szklance wody wytworzyły klimat sprzyjający odnowie" ${ }^{\text {". }}$. W ostatecznym rozrachunku jednak, w realiach nieustannie zmieniających się politycznych koniunktur, Gombrowicz nieodmiennie okazuje się twórcą tyleż niewygodnym, co trudnym do ostatecznych ideologicznych przyporządkowań.

Podmiot mówiący w analizowanych tekstach próbuje nieustannie dystansować się wobec tworzonych przez siebie konstruktów „europejskości”. Czyni to jednak niejako ad hoc, bez nadrzędnej wizji kulturowych porządków czy procesów - tym samym zbiór artykułów, choć jednorodny tematycznie, nie staje się spójną propozycją epistemologiczną, wizją zbiorowej tożsamości czy poradnikiem zachowań erotycznych, lecz niejako mimochodem odsłania różne aspekty ówczesnego permanentnego nieprzystosowania Gombrowicza do rzeczywistości, w której się znalazł. Nieprzystosowania, które usiłował przesłonić fingowaną na użytek czytelników lokalnej prasy „europejskością”. Tym samym owa „europejskość” funkcjonuje jako specyficzny, kształtowany na doraźne potrzeby pojedynczej wypowiedzi „,punkt odniesienia”, pozbawiony jednak

\footnotetext{
${ }^{6}$ R. Gombrowicz, Wstęp, [w:] W. Gombrowicz, Nasz dramat erotyczny, s. 5.

${ }^{7}$ J, Franczak, Gombrowicz: reloaded, Dekada Krakowska 2018 nr 2/3, s. 48.

${ }^{8}$ W. Gombrowicz, Nasz dramat erotyczny, s. 73.
} 
substancjalnego ciężaru, historycznego ugruntowania, realnego zakotwiczenia w wiedzy wspólnotowej czy nawet jednostkowym doświadczeniu?

Aktorzy erotycznego dramatu - kobiety i mężczyźni — to figury płaskie o ściśle przyporządkowanych ponadindywidualnych cechach. Natomiast ich relacje, poddawane krytycznemu oglądowi i ukazywane jako ściśle upodrzędnione wobec obowiązujących wówczas konwenansów, porażają nieautentycznością, powierzchownością i nietrwałością. W odróżnieniu jednak od kobiecości — ukazywanej poza realnymi uwarunkowaniami społecznymi, etnicznymi czy kulturowymi - męskość przedstawiona została w nieco bardziej złożony sposób. Tomasz Kaliściak przekonywał:

Gombrowicz z ziemiańskiego panicza, którego zwykł odgrywać w salonach Warszawy, jako europejski imigrant staje się w Argentynie przedstawicielem plebsu, niejako odgórnie przypisanym do męskości sfeminizowanych czy też odmieńczych. Ta deklasacja i odrzucenie przez argentyński salon w sposób znaczący zbliżyły go do niższości wpływając na rewizję postrzegania męskości ${ }^{10}$.

Formy męskości prezentowane w Naszym dramacie erotycznym zdają się bowiem — już na pierwszy rzut oka - najbardziej przystawać do burzycielskiego przesłania pisarstwa Gombrowicza, postrzeganego jako jego całościowy wkład w przemiany kultury.

Twórczość Gombrowicza pozostaje częścią południowoamerykańskiego dziedzictwa kulturowego. Marzena Grzegorczyk w artykule poświęconym współczesnemu funkcjonowaniu spuścizny pisarza w Ameryce Południowej (zamieszczonym w tomie Grymasy Gombrowicza) podsumowywała:

W kontekście latynoamerykańskim, gdzie stawką operacji przeprowadzanych w dziedzinie kultury jest zachowanie różnic i unikanie wymuszonej homogenizacji, Gombrowiczowski płynny energetyczny system semiotycznego odnowienia jest szczególnie pociągający [...] Gombrowiczowska celebracja niedojrzałości i bezformia oraz jego wiara $\mathrm{w}$ ich sytuacyjną wyższość usuwa proces wytwarzania narodowej formy $\mathrm{z}$ osi własnej teleologii i sytuuje go na pozycjach autonomicznych wobec hegemonii zachodnich kultur form dojrzałych ${ }^{11}$.

$\mathrm{Z}$ tej perspektywy także analizowane artykuły prasowe, sporządzane przede wszystkim w celu uzyskania wymiernych i koniecznych korzyści materialnych, stanowią kolejną emanację buntu przeciw formie oraz wiary, że samo wskazanie, a następnie uznanie/uświadomienie opresyjności formy rodzi chęć jej odrzucenia.

Dostrzeganie specyfiki rodzącej się odrębności kulturowej nie uwalniało Gombrowicza w pełni od nabytych wcześniej nawyków interpretowania reguł wspólnotowego życia - co wynikać mogło ze swoistej inercji światopoglądowej, warunkowanej wzrastaniem w określonej kulturze, a ujawniającej się w fazie formułowania poszczegól-

\footnotetext{
${ }^{9}$ Nieustanne gry autokreacyjne Gombrowicza — najwyraźniej uwidoczniające się w Dziennikach - skoncentrowane na problemach rozmaicie definiowanych „tożsamości” mają wymiar celowego (celowo komponowanego, redagowanego, wielokrotnie dookreślanego), nadto kierowanego do konkretnych grup odbiorców prowokacyjnego wyzwania (zob. m.in.: J. Olejniczak, „, Kłamstwo nieprzerwanie nas drąży”. Cztery szkice o Gombrowiczu, Katowice 2003; E. Kobylecka-Piwońska, „Dziennik argentyński”, czyli jakiego Gombrowicza czyta się w Buenos Aires, Teksty Drugie $2016 \mathrm{nr} 1)$.

${ }^{10}$ T. Kaliściak, Męskości argentyńskie a „Trans-Atlantyk” Witolda Gombrowicza, Autobiografia. Literatura. Kultura. Media 2016 nr 1, s. 73.

${ }_{11}^{11}$ M. Grzegorczyk, Kształt życia i bezkształt tradycji. Argentyńska spuścizna Witolda Gombrowicza, [w:] Grymasy Gombrowicza. W kręgu problemów modernizmu, społeczno-kulturowej roli ptci i tożsamości narodowej, red. E. Płonowska-Ziarek, Kraków 2001, s. 181-182.
} 
nych „,argumentów”. Tomasz Kaliściak wskazywał na szczególną optykę zastosowaną w tekstach złożonych w tomie Nasz dramat erotyczny, przekonując, iż Gombrowiczowskie postrzeganie południowoamerykańskiego mężczyzny „nie jest wolne od Europo- i androcentrycznego punktu widzenia, który pozwala mu uznać europejskiego mężczyznę za lepszego pod wieloma względami i lepiej przygotowanego do życia"12. Trzeba jednak dodać, że ogląd ów okazuje się w ostatecznym rozrachunku zabiegiem retorycznym, służącym przede wszystkim propagowaniu idei zmiany — nie tylko pożądanej, ale i uznawanej za konieczną.

Pisarstwo Gombrowicza nieustannie poddawane jest interpretacjom przez kolejne pokolenia badaczy. Marian Bielecki tworzący często „podwojone”, komparatystyczne portrety pisarza, porównując dziennikową spuściznę Gide’a i Gombrowicza, podkreślał biegunowo różne oceny funkcjonujące $\mathrm{w}$ dzisiejszym odczytywaniu pisarstwa autora Trans-Atlantyku: „Gombrowicz bywa czasem w optyce gombrowiczologów: lewicowy i prawicowy, feministyczny czy queerowy i mizoginiczny, prosemicki i antysemicki, plebejski i arystokratyczny, awangardowy i konserwatywny"13. I tu powraca pytanie, na ile strategie lekturowe zależą od kapryśnej woli badacza/odbiorcy, na ile zaś pozostają pochodną tekstowych zabiegów pisarza, usiłującego uniemożliwić tworzenie prostych i jednoznacznych odczytań swoich utworów.

Doceniana od początku przez interpretatorów Gombrowiczowska aporetyczna, daleka od konkluzywności poetyka pisania dziennikowego ${ }^{14}$ pozwalała twórcy od razu wymykać się uproszczonym odczytaniom. Tymczasem natrętna nieraz konkluzywność gazetowych artykułów może dziś skłaniać raczej do jednoznacznych, niezbyt aprobatywnych osądów i dopiero bardziej wnikliwa, w tym przypadku niejako „empatyczna” lektura, pozwala w nich śledzić silnie determinowany przez warunki zewnętrzne etap drogi twórczej pisarza, prowadzącej od egzystencjalnego zagubienia w obcej rzeczywistości do głęboko uwewnętrznionego imperatywu rozbijania tradycyjnych relacji między jednostką a wspólnotą. Terry Eagleton w swoim Końcu teorii przekonywał wiele dekad później, iż nie ma dziś powrotu do „idei wspólnotowości pochodzącej ze świata rozpadającego się właśnie na naszych oczach. Historia ludzkości jest obecnie postkolektywistyczna, jak i postindywidualistyczna i choć wywołuje to wrażenie próżni, może również oznaczać szansęe"15. Gombrowicz wydaje się — nawet w swoich niedopracowanych i falsyfikowanych artykułach — prekursorem wszelkich dzisiejszych ,postycznych" wizji zbiorowych rytuałów.

Przynależność do wspólnoty nie powinna wszak wynikać z narzucanych przyporządkowań. Eagleton twierdził:

Musimy wyobrazić sobie nowe formy przynależności, które w naszym świecie będą z konieczności raczej złożone niż monolityczne. Niektóre z nich będą miały coś z intymności relacji plemiennych lub wspólnotowych, podczas gdy inne będą bardziej abstrakcyjne, zapośredniczone i rozmyte ${ }^{16}$.

\footnotetext{
${ }^{12}$ T. Kaliściak, Męskości argentyńskie, s. 67.

${ }^{13}$ M. Bielecki, Pomiędzy prywatnym a publicznym. Dzienniki André Gide'a i Witolda Gombrowicza, Archiwum Emigracji 2017 nr 24-25, s. 234.

${ }^{14}$ Tamże, s. 234. Bielecki przekonuje także, iż Gombrowicz ,z proteuszowości uczynił idée fixe, ale jego znakiem firmowym jest raczej radykalizm, swoista kategoryczność czy pryncypialność nawet, oraz idiomatyczność poetyki" (tamże, s. 222).

${ }^{15}$ T. Eagleton, Koniec teorii, przeł. B. Kuźniarz, Warszawa 2012, s. 27.

${ }^{16}$ Tamże.
} 
Gombrowicz, konstruując swoje wizje „europejskości”, odsłaniał zarazem, a może przede wszystkim ich sztuczność, a zatem i nieostateczność, i temporalność, i owo nieuchronne „rozmycie”. Autor Końca teorii mówił wprost: „Ludzie w równym stopniu potrzebują swobody i mobilności, co tradycji i poczucia przynależności. Zakorzenienie to wciąż aktualny ideał"17. Zadaniem, jakie postawił sobie w połowie lat 40 . XX wieku Gombrowicz — oprócz nadziei na zarobek — było wykorzystanie funkcjonujących wówczas potrzeb wspólnotowego zakorzenienia do przemycania specyficznej wywrotowej kontrabandy ideowej oraz podkładania ładunków wybuchowych pod gmach skostniałych tradycji.

Terytorialną przynależność do zbiorowości „południowoamerykańskiej” czy „europejskiej” można było przecież unieważnić w prostym — jego zdaniem — geście zakwestionowania jej formującej roli jako istotnego czynnika determinującego pojedynczą egzystencję. Należy pamiętać, że także dzisiejsze renarracje nowoczesnej z ducha opowieści o wyzwoleniu podlegają ciągłym przekształceniom oraz doraźnemu użytkowaniu, nacechowanemu dążeniem do partykularnych korzyści. Opisując ten powtarzalny mechanizm, Przemysław Czapliński twierdził z przekonaniem, że konstruowanie nowych narracji u schyłku nowoczesności wymaga (choćby jako kontekstu negowanego czy dekonstruowanego) znajomości wielkich opowieści wykształconych przez nowoczesność - zawsze bowiem zrozumienie nowego społeczeństwa jako nowego porządku narracyjnego wymaga przemyślenia idei dawnych ${ }^{18}$.

Tymczasem Gombrowicz piszący dla snobistycznego argentyńskiego mieszczaństwa wykorzystywał zmistyfikowane założenia europejskiego modernizmu, by za ich pomocą propagować rozluźnienie reguł i konwenansów wspólnotowej egzystencji. Falsyfikowana przez niego dla doraźnych celów ,europejskość” okazywała się przede wszystkim poręcznym narzędziem ułatwiającym retoryczne dywagacje kierowane ku Argentyńczykom potrzebującym rzekomo pomocy na drodze ku erotycznemu wyzwoleniu. Literatura wyrastająca ponad przeciętną masową produkcję tekstów kultury z reguły wypracowuje mechanizmy chroniące przed zbyt uproszczoną, utylitarną lekturą - a pisarze mają świadomość funkcjonowania w przestrzeni historycznie determinowanych obiegów społecznej komunikacji. Jednak Gombrowicz w swych prasowych wypowiedziach zrezygnował $\mathrm{z}$ aspektu historycznego osadzenia rozważań na rzecz całkowicie ahistorycznych, a pozornie powiązanych z terytorium konstruktów tożsamościowych, właśnie dlatego, że takie klisze okazywały się najbardziej poręczne w realiach cywilizacyjnej zależności, którym warto było przeciwstawiać projekty autonomii kulturowej i obyczajowej.

Pomimo permanentnie odczuwanej obcości i wykluczenia pisarz mógł w ten sposób próbować wejść w dialog ze zbiorowością - choćby ufundowany na tożsamościowych grach i przebierankach. Marian Bielecki pisał o podmiocie Dziennika, że konstytutywny dla niego okazuje się akt przesunięcia punktu ciężkości z prywatnego na publiczne. Ten gest badacz odczytuje jako próbę wyjścia poza autokreację, poza osobistą idiosynkrazję, poza społeczną wyniosłość modernistycznego artysty — a także próbę usytuowania w przestrzeni publicznej, w pewnej wspólnocie, w prawie powszechności, ale bez pogwałcenia prawa autonomii ${ }^{19}$. Jak się zdaje, cykl artykułów z lat 40. był dla Gombrowicza także taką próbą całkiem jeszcze prowizorycznego i wa-

\footnotetext{
${ }^{17}$ Tamże.

${ }^{18}$ Zob.: P. Czapliński, Polska do wymiany. Późna nowoczesność i nasze wielkie narracje, Warszawa 2009, s. 16.

${ }^{19}$ M. Bielecki, Pomiędzy prywatnym a publicznym, s. 234.
} 
runkowego sytuowania się z jednej strony wewnątrz zbiorowości, a jednocześnie nieodmiennie i niestrudzenie — wobec niej.

Poszukiwanie w literaturze śladów zbiorowych doświadczeń może i odbiorców prowadzić do uproszczonego oraz utylitarnego traktowania tekstów. Kiedy Dorota Kołodziejczyk w artykule Światowa Republika Literatury czy tandetny supermarket przestrzegała, że interpretacyjny paradygmat tożsamości „często ogranicza rolę literatury do metonimicznej reprezentacji społeczności (narodowej, etnicznej, diasporycznej) i czyni z badań nad literaturą nieco łatwiejszą logistycznie wersję antropologii kulturowej czy area studies" ${ }^{20}$, miała na uwadze ten właśnie ograniczający aspekt lekturowych poszukiwań. W przypadku Naszego dramatu erotycznego widać szczególnie wyraźnie, jak błędny może okazać się taki tryb lektury. Współczesne czytanie analizowanych tekstów Gombrowicza prowadzić winno raczej do namysłu nad sposobami tekstowego przezwyciężania owych „paradygmatów tożsamości” w odkrywanym tu jednostkowym wysiłku twórcy, by (jak zawsze) czynić przede wszystkim gesty osobne: o wymiarze zarazem autokreacyjnym, jak i emancypacyjnym - wciągając przy tym odbiorców w szczególną ,grę”. Jerzy Jarzębski, w swoim klasycznym już rozpoznaniu, tak dookreślał te relacje:

Pisarz przecie gra wśród ludzi i z ludźmi, każda lektura jego książki raz jeszcze wskrzesza rozgrywkę — choćby sam autor dawno był już pośród zmarłych. Nie tylko bowiem on „gra w Gombrowicza” - także i my wszyscy „gramy w Gombrowicza”, poddajemy się — potulnie lub pełni wewnętrznego buntu — oddziaływaniu jego osoby, gramy według jego reguł o wzbogacenie własnego ,ja” bądź o zachowanie autentyczności, suwerenności w zetknięciu z jego ,ja”21.

„Wewnętrzny bunt” — niemal odruchowy przy lekturze Naszego dramatu erotycznego — uśmierzyć może jedynie uświadomienie sobie, kto i w jakich warunkach napisał ten tekst, oraz przyjęcie reguł gry prowadzonej wówczas przez pisarza.

„Europejskość” staje się w takim ujęciu przynależnością wciąż od nowa konstruowaną i jednocześnie odrzucaną — punktem odniesienia, jednak nie stałym, lecz wciąż przesuwanym: zbliżanym i oddalanym zarówno w płaszczyźnie horyzontalnej (czyli w sferze tożsamościowych autoidentyfikacji), jak i wertykalnej (w sferze ich wartościowania). Nie jest zatem koncepcją dotyczącą zbiorowości, którą należy porównywać z wieloma jej podobnymi, lecz prywatnym projektem wykorzystania składających się na „europejskość” stereotypów i klisz. Zostaje przy tym powtórzony wcześniej sprawdzony „mechanizm obronny”. Błażej Warkocki, pisząc w swoim studium Pamiętnik afektów z okresu dojrzewania o ,peryperformatywnych okolicach niedojrzałości”, wskazywał, że wiele wypowiedzi młodego Gombrowicza gromadziło się wokół „niedojrzałości”, ponieważ jej „silna performatywna moc opiera się na eufemizowaniu »homoseksualnośći« umieszczonej w ramie modalnej freudyzmu"22. Pisarz — zmagający się ze złymi wspomnieniami dotyczącymi odbioru jego debiutu — postarał się

${ }^{20}$ D. Kolodziejczyk, Światowa Republika Literatury czy tandetny supermarket? Peryferyjne miejsca i globalne szlaki kulturowe we wspótczesnej literaturze porównawczej, [w:] Historie, społeczeństwa, przestrzenie dialogu. Studia postzależnościowe w perspektywie porównawczej, red H. Gosk, D. Kołodziejczyk, Kraków 2014, s. 223.

${ }^{21}$ J. Jarzębski, Gra w Gombrowicza, Warszawa 1982, s. 9. Jarzębski już wówczas podkreślał, że „gra w Gombrowicza” oderwała się dawno od autora, a zmieniła się w ,instytucję społeczną”, w której „każdy z nas w procesie aktywnego odbioru, interpretacji wnosić może nowe wartości" (tamże, s. 9).

${ }^{22}$ B. Warkocki, Pamiętnik afektów z okresu dojrzewania. Gombrowicz - queer - Sedgwick, Warszawa 2018, s. 268. 
jednak o wykolejenie eufemistycznej i piętnującej wypowiedzi performatywnej, a następnie przyjął ,niedojrzałość" na powrót do swojego rejestru, a z czasem również do repertuaru autointerpretacyjnych pojęć ${ }^{23}$. Takim autointerpretacyjnym pojęciem stała się również „europejskość” — oznaczająca w owym momencie biograficznym obcość i „niższość”, stała się narzędziem pozwalającym na formułowanie aktów autonomii i emancypacji, a nawet wykreowanie podmiotu stawiającego się w roli przewodnika dla zbiorowości, w której pisarz nie zdołał jeszcze odnaleźć własnego miejsca. Paradoksalnie więc - z tekstów słabych, nieliterackich, kliszowych — wyczytać można, choć przy dużej dozie dobrej woli, znany skądinąd autokreacyjny i zarazem subwersywny potencjał pisarza.

Odbiorca nie dowiadywał się wówczas, jak i teraz nie dowiaduje się, co prawda, czym jest „europejskość”, ale zyskuje przekonanie, że może ją wytwarzać na własny użytek. Gombrowicz pytał retorycznie: „Czyż erotyczny postęp Europy w ostatnich czasach był owocem programów i teorii?"24. Oczywiści nie — odpowiadał — jednak to one właśnie stały się zaczynem dyskusji i sporów, które ostatecznie ,przekonały współczesnego Europejczyka, że sam musi sobie stworzyć własną obyczajowość, podobnie jak jego przodkowie stworzyli sobie własną"25. W masce Jorge Alejandro pisarz przekonywał, że wszelkiego rodzaju „kult tradycji” to, co prawda „rzecz wspaniała, ale ten, kto jedynie imituje przodków, nie naśladuje ich właściwie, bo staje się identyczny z nimi pod wszelkimi względami z wyjątkiem jednego — twórczego ducha, jakiego oni okazywali w swoim czasie"26.

Gombrowicz konstruował taką oto wizję aprobowanego, a zarazem projektowanego jako wzór „porządku dziejów”:

W Ameryce Łacińskiej nigdy nie doszło do takiej generalnej bitwy między młodymi i starymi, jaka rozegrała się w Europie i z jakiej młodzi wyszli zwycięsko. Tutaj młodzi są zbyt spokojni, nie buntują się wystarczająco energicznie, toteż wypada przypomnieć im surowo, że nie dopełniają najświętszego obowiązku młodości ${ }^{27}$.

Propagowane zatem „najświętsze zadanie młodych” to w istocie przetwarzanie wedle własnych potrzeb wszelkich istniejących wzorców. Natomiast „europejskość”, modelowana jako stała gotowość odrzucania „europejskości”, miała służyć za wzór społecznościom południowoamerykańskim — to zarazem pierwociny założeń pozwalających zastąpić ideę jednego tożsamościowego uniwersum, wieloma niekoherentnymi (i niedążącymi do koherencji) ideami „poliwersum” — w rzeczywistości kształtowanej poprzez poszanowanie prawa do współistnienia różnic.

Zagłębienie się w tekst oraz okoliczności jego powstania prowadzić może do uznania za prawomocny wniosku, że także publicystyczne wprawki wpisują się w nadrzędną wizję kulturową stworzoną przez pisarza. Jak zauważa Marzena Grzegorczyk, Gombrowicz przedstawia taki model ponadkulturowy, który zamiast prostego konsumowania importowanych wytworów kultury, wskazuje na konieczność przeniesienia miejsca ich produkcji w regionalną lokalizację, by tym samym wyrwać się spod ich autorytarnego wpływu $^{28}$. Konstrukt „europejskości”, jakoby znanej i zrozumiałej, a nieustannie przeciwstawianej dopiero poznawanym i re-konstruowanym na własne potrzeby realiom

\footnotetext{
${ }^{23}$ Tamże, s. 276.

${ }^{24}$ W. Gombrowicz, Nasz dramat erotyczny, s. 73.

${ }^{25}$ Tamże.

${ }^{26}$ Tamże.

${ }^{27}$ Tamże, s. 73-74.

${ }^{28}$ M. Grzegorczyk, Ksztalt życia, s. 182.
} 
południowoamerykańskim, odsłania swoją użyteczność - właśnie w ramach jednostkowego (a nie regulowanego przez zbiorowość) wytwarzania tożsamości.

W wariancie stworzonym przez Gombrowicza w szczególne trudnym momencie biograficznym owa europejska ,tradycja” - traktowana z dezynwolturą i prowokacyjnie dekonstruowana - stała się zbiorem dyrektyw dla przeprowadzenia pożądanego i oczekiwanego zrzucenia formy. Mówiąc inaczej, w Naszym dramacie erotycznym odbiorca staje się świadkiem koniecznej, niemal radosnej, ożywczej i progresywnej destrukcji obowiązujących wzorców - po raz kolejny wiodących ku wyzwoleniu z narzucanych przez zbiorowość ograniczeń.

\section{LITERATURA}

Antonik D., Pisarz jako marka. Literatura w kulturze audiowizualnej spoleczeństwa informacyjnego, Kraków 2014.

Bielecki M., Pomiędzy prywatnym i publicznym. Dzienniki Andre Gide'a i Witolda Gombrowi$c z a$, ,Archiwum Emigracji” 2017, nr 24-25.

Czapliński P., Polska do wymiany. Późna nowoczesność i nasze wielkie narracje, Warszawa 2009.

Eagleton T., Koniec teorii, przeł. B. Kuźniarz, Warszawa 2012.

Franczak J., Gombrowicz: reloaded, „Dekada Krakowska” 2018, nr 2/3.

Głowiński M., Gombrowicz i nadliteratura, Kraków 2002.

Gombrowicz W., Nasz dramat erotyczny, przeł. I. Kania, Kraków 2003.

Grzegorczyk M., Ksztalt życia i bezksztalt tradycji. Argentyńska spuścizna Witolda Gombrowicza, [w:] Grymasy Gombrowicza. W kręgu problemów modernizmu, społeczno-kulturowej roli płci i tożsamości narodowej, red. E. Płonowska-Ziarek, Kraków 2001.

Jarzębski J., Gra w Gombrowicza, Warszawa 1982.

Kaliściak T., Męskości argentyńskie a „Tran-Atlantyk” Witolda Gombrowicza, „Autobiografia. Literatura. Kultura. Media” 2016, nr 1.

Kobylecka-Piwońska E., „,Dziennik argentyński”, czyli jakiego Gombrowicza czyta się w Buenos Aires, „Teksty Drugie” 2016, nr 1.

Kołodziejczyk D., Światowa Republika Literatury czy tandetny supermarket. Peryferyjne miejsca i globalne szlaki kulturowe we współczesnej, [w:] Historie, społeczeństwa, przestrzenie dialogu. Studia postzależnościowe w perspektywie porównawczej, red. H. Gosk, D. Kołodziejczyk, Kraków 2014.

Literatura polska po 1989 roku w świetle teorii Pierre'a Bourdieu. Podręcznik, red. G. Jankowicz, P. Marecki, M. Sowiński, Kraków 2015.

Olejniczak J., ,,Kłamstwo nieprzerwanie nas drąży”. Cztery szkice o Gombrowiczu, Katowice 2003.

Warkocki B., Pamiętnik afektów z okresu dojrzewania. Gombrowicz - queer - Sedgwick, Warszawa 2018.

\section{NASZ DRAMAT EROTYCZNY BY WITOLD GOMBROWICZ: 'EUROPEANNESS' ON SALE}

The essay is an analysis of a serious of newspaper articles written by Witold Gombrowicz in the 1940s in Argentina, which were later published in a volume entitled Nasz dramat erotyczny [Our Erotic Drama]. The idea of collective identity and the changing patterns of its construction are key to the analysis. The writer's individual projects prove useful in the contemporary analysis of wartime texts by Gombrowicz, as they highlight the specificity of various elements of European and South American cultural identities, which are often contradictory.

KEY WORDS: identity, Europeanness, South America, form, immaturity, Witold Gombrowicz SŁOWA KLUCZOWE: tożsamość, europejskość, Ameryka Południowa, forma, niedojrzałość, Witold Gombrowicz 